\title{
The Post-Partum Exfoliative Vaginal Cytology of Local Goats in Northern Algeria
}

\author{
Achour YAHIA ${ }^{1 *}$, Rachid KAIDI ${ }^{1}$, Khadidja HAMRAT ${ }^{2}$ \\ ${ }^{1}$ Laboratory of biotechnology related to animal reproduction, Institute of Veterinary Sciences. University \\ of Blida 1, Algeria. \\ ${ }^{2}$ Directorate of Agricultural Services. Blida, Algeria \\ *Corresponding author: achourveto@yahoo.fr
}

Bulletin UASVM Veterinary Medicine 73(1) / 2016,

Print ISSN 1843-5270; Electronic ISSN 1843-5378

DOI:10.15835/buasvmcn-vm: 11596

\begin{abstract}
The aim of our study was to determine the approximate length of the post-partum period of the local goat breed in Algeria. Based on the identification of cell layers of the vaginal mucosa (vaginal cytology) from the first week after parturition. In this work we used 13 goats aged 2 to 4 years and weighing 18 to $34 \mathrm{~kg}$ live weight. The experimental study was conducted at the experimental farm of the agro-veterinarian faculty of the Blida University. By swab, vaginal smears were made for each goat twice a week to 2 or 3 days interval from the seventh day post partum to 80 days post partum. We realized 312 smears of vaginal mucosa in total (stained with My-GrunwaldGiemsa staining) and we identify the resumption of the post-partum sexual activity when the superficial epithelial cells predominate in the smears. In the light of our study, the average interval parturition-resumption of sexual activity in the local goat in northern Algeria is short, estimated at 21,45 $\pm 3,56$ days with a variation ranging from 16 to 27 days.
\end{abstract}

Keywords: Local goat, post-partum, vaginal cytology

\section{INTRODUCTION}

The post partum anoestrus was considered to be the period between partum and the occurrence of the first estrus (Freitas et al., 2004).

The postpartum period is defined as the period immediately following parturition and during which no normal estrus is manifested. With variable duration, it ends with the return of physiological and normal behavioral ovarian cycles.

The interval between parturition and the first post-partum estrus is an important trait which contributes to the productive efficiency (Greyling, 2000).

According Baril et al., (1993), parturition is followed by a period of sexual rest for two reasons of internal origin. The first is the time required for uterine involution. The second is the inactivity of the ovary, mainly of central origin since this one is not sufficiently stimulated by gonadotrophin hormones.
The post-partum heat period in Black Bengal does vary within the different seasons (Fakruzzaman et al., 2012).

The cytological changes in the vaginal epithelium of the Angora doe appeared to be influenced by cyclical ovarian activity and could be used to assess ovarian activity (Pretorius, 1977).

In our knowledge, no study has been published concerning the postpartum period of the Algerian local goat, so in this work, we try to determinate the post partum duration of the local goat in northern Algeria by the exam of vaginal exfoliative cytology changes.

\section{MATERIALS AND METHODS}

Thirteen local breed goats aged 2 to 4 years, weighing between 18 and $34 \mathrm{~kg}$, are used in our experimentation that took place in the experimental farm of agro Veterinarian Faculty of the Blida University (Algeria). This Farm is located in the Mitidja region, having a Mediterranean 
climate, characterized by cold and rainy winters, hot and dry summers. Animals are conducted in a semi extensive system and received $500 \mathrm{~g}$ of concentrate per day per head. Water is distributed at will.

Our work is based on the identification of cell layers of the vaginal mucosa (vaginal cytology) from the first week after parturition. Vaginal smears were collected from each doe twice a week to 2 or 3 days interval from the $7^{\text {th }}$ day post partum to the $80^{\text {th }}$ day post partum. We realized in total, 312 smears.

The smear collection procedure involved using vaginoscope for parting the vulva lips and inserting a $10 \mathrm{~cm}$ long cotton-tipped sterile swab into the vagina to a depth of about $5-7 \mathrm{~cm}$. The swab inside the vagina was rotated through 2-3 revolutions against the vaginal wall. The swab was withdrawn and rolled on a clean glass slide to form two parallel tracks of smear material on the glass surface. The smear was immediately fixed by (spray cytofixator), air-dried and stained by the Giemsa stain.

The vaginal cells are classified under a light microscope into three basic cell types with different cell diameters; as a superficial squamous cell with light cytoplasm, intermediate squamous cells and parabasal cells (Dudek, 2004). Each cell type was counted and then expressed as a percentage of totals (Lamond and Lang, 2005).

\section{RESULTS AND DISCUSSION}

To determine the first postpartum estrus we looked the first smear that contained the highest percentage of superficial epithelial cells for each

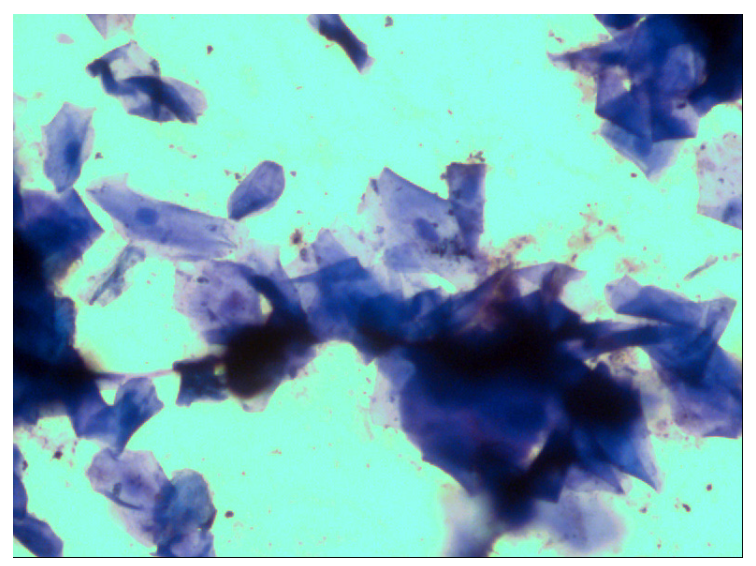

goat, this last indicates the resumption of sexual activity (Fig. 1).

In this study, it appears that post-partum sexual activity resumption, determined by vaginal cytology evaluation (smears with predominance of superficial epithelial cells) starts on the $16^{\text {th }}$ day after parturition in the goat 5103. It starts on the $18^{\text {th }}$ day, on the $19^{\text {th }}$ day, on the $21^{\text {st }}$ day, on the $22^{\text {nd }}$ day, on the $26^{\text {th }}$ day and on the $27^{\text {th }}$ day, respectively for the goats 5104, (5100 and C116), (5101, 3070 and 104946), 7100, (89440 and 104997), 104906.

Contrarily, in the goats 5102 and 6100, the vaginal mucosa smears observation doesn't reveal a resumption of post-partum sexual activity (estrus or predominance of the superficial epithelial cells in the smears) throughout the study.

The moment of the sexual activity beginning (in days) after parturition, or the duration between parturition and the first estrus apparition determined by the exploration of the exfoliative vaginal cytology for the different goats is reported in the following table (Tab. 1).

The average duration of the post-partum sexual activity resumption (determined by vaginal cytology) was $21,45 \pm 3,56$ days. In the goats 6100 and 5102, we didn't identify smears with predominance of superficial cells during the length of the study, but the mostly presence of intermediate cells in large quantities.

These values are comparable to the results that have been reported by (Chemineau, 1983; Hafez and Hafez, 2000; Riera, 1982), postpartum intervals qualified short, 15 to 30 days are often noticed in goats. Mascarenhas et al., (1995), reported that serrana Goats kidding in October had a significantly shorter postpartum anestrous

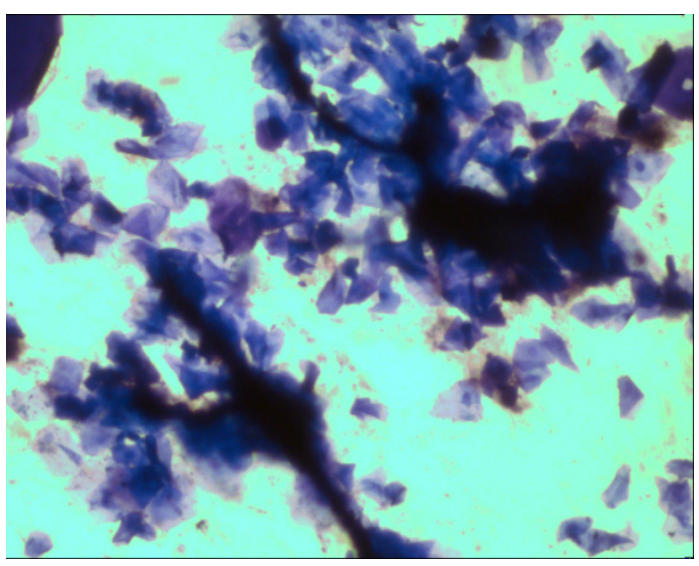

Fig. 1. Smears with predominate superficial epithelial cells. 
period (33 $\pm 9,4$ days). Degefa et al., (2006), found that the uterus reassumed normal non-gravid macroscopic and microscopic characteristics by day 19 post-partum in Balady goats. While Grayling and van Niekerk (1991) noted the involution process of the uterus was macroscopically complete by approximately 28 days post-partum in the Boer goat.

The mean duration of the post-partum anoestrous period in the Boer goat is quoted as being $55,5 \pm 24,9$ days with the period being $53,2 \pm 14,3$ days for does bearing singletons, $58,5 \pm 30$ days for does with twins and $61,7 \pm 30,7$ days for does bearing triplets (no significant difference) (Greyling, 1988). Chemineau (1983) reported that most Creole goats become cyclic 70 days post-partum, with a first post-partum estrous period being $21,05 \pm 8,9$ days following parturition.

The post-partum heat period in Black Bengal does vary within the different seasons. The postpartum heat period of does is comparatively higher in winter (94 $\pm 2,31$ days) than those of summer $(83,33 \pm 2,03$ days $)$ and rainy season $(76,33 \pm 6,36$ days) (Fakruzzaman et al., 2012). The length of post-partum anoestrus can vary substantially in tropical climate goats and food availability is the main environmental factor that determines the length of post-partum anoestrus (GonzalezStagnaro, 1984). The authors concluded that season of partum have a major influence on the time of sexual activity reinitiating after partum (Freitas et al., 2004). The interval whelpingfirst heat is strongly influenced by the time of parturition. The interval can be short 5 to 6 weeks or longer 27 weeks for certain breeds. When parturition occurs during the period of sexual activity, the ovarian activity can resume and goats can conceive (Jainudeen et al., 2000).

In the goat 6100 and the goat 5102, we have not seen estrus resumption by vaginal cytology (predominance of superficial cells in the smears). This could be due to the presence of silent ovulations unaccompanied by estrous behaviors, which are described in the goats by Delgadillo et al., (1997), in tropical or subtropical regions, and Corteel and Cognié (1985) in temperate regions. Darquaoui and Elkhaldi (1992) found that the proportion of goats that had ovarian activity was still higher than that of subjects who showed signs of heat. This characteristic indicates the existence of ovulations unaccompanied with heat. The incidence of silent ovulations (15$25 \%$ ) was relatively high in D'man breed goat in Morocco. Work performed on Creole goats by the progesterone assay show that the first postpartum ovulation not accompanied by estrous behavior can be noted in the third week after the whelping (Baril et al., 1993).

Tab. 1. Resumption of sexual activity after parturition determined by analysis of vaginal cytology smears.

\begin{tabular}{ccc}
\hline Goat number & Age (months) & $\begin{array}{c}\text { Day of the first estrus apparition (superficial } \\
\text { cells predominate in the smear) }\end{array}$ \\
\hline 5101 & 72 & 21 \\
\hline 6100 & 28 & ND \\
\hline 5102 & 24 & ND \\
\hline C116 & 66 & 19 \\
\hline 3070 & 45 & 21 \\
\hline 104946 & 58 & 21 \\
\hline 89440 & 38 & 26 \\
\hline 5103 & 24 & 16 \\
\hline 104906 & 36 & 27 \\
\hline 7100 & 60 & 22 \\
\hline 5100 & 58 & 19 \\
\hline 5104 & 54 & 18 \\
\hline 104997 & 46 & 26 \\
\hline Mean \pm S.E.M & $21,45 \pm 3,56$ \\
\hline ND: Not determined(There is not estrus throughout the study).
\end{tabular}




\section{CONCLUSION}

In the light of our study, the mean interval parturition-resumption of sexual activity in the local goat in northern Algeria determined by analysis of vaginal cytology smears is short estimated at $21,45 \pm 3,56$ days. Other works are needed to study and characterize the different reproductive and productive parameters of local goats in Algeria.

\section{REFERENCES}

1. Baril G, Chemineau P, Cognie Y, Guerin Y, Leboeuf B, Orgeur P, Vallet JC (1993). Manuel de formation pour l'insémination artificielle chez les Ovins et les Caprins. Etude FAO Production et Sante Animales. Rome 83, M-21, 92.

2. Chemineau P (1983). Effect of oestrus and ovulation of exposing creole goats to the male at three times of the year. Journal of Reproduction and Fertility 67:65-72.

3. Corteel JM, Cognié Y (1985). Aspects dynamiques de la genèse des cycles sexuels chez la chèvre française à vocation laitière. $\mathrm{I}^{\mathrm{er}}$ Colloque International sur Reproduction des Caprins, Drummondville, 35-43.

4. Degefa T, Ababneh MM, Moustafa MF (2006). Uterine involution in the post-partum Balady goat. Veterinarski Arhiv 76 (2):119-133.

5. Delgadillo J A, Malpaux B, Chemineau P (1997). La reproduction des caprins dans les zones tropicales. Productions Animales INRA 10(1):33-41.

6. Derquaoui L, El Khaledi O (1992). Evaluation de l'activité sexuelle pendant la saison de baisse de fertilité chez la chèvre de race D'man. Small ruminant research and development in Africa. Proceedings of the Second Biennial Conference of the African Small Ruminant Research Network AICC, Arusha, Tanzania, ILRI, 7-11 December.

7. Dudek RW (2004). High Yield Histology. 3rd ed, Lippincott Williams and Wilkins, Philadelphia, 222-223.

8. Fakruzzaman M, Akter QS, Husain SS, Khandoker MAMY, Apu AS, Islam MR (2012). teristics of Black Bengal Does
Under Intensive Condition. Iranian Journal of Applied Animal Science 2(1):89-95.

9. Freitas VJF, Rondina D, Nogueira DM, Simplicio AA (2004). Post-partum anoestrus in Anglo-Nubian and Saanen goats raised in semi-arid of North-eastern Brazil. Livestock Production Science 90:219-226.

10. Gonzalez-Stagnaro C (1984). Comportamiento reproductivo de las razas locales de rumiantes em el tropico americano. In: Chemineau P, Gauthier D, Thimonier J (Eds). Reproduction des ruminantes en zone tropicale, Les Colloques de l'INRA, Point à Pitre, Guadeloupe 1:1-8.

11. Greyling JPC (1988). Reproductive physiology in the Boer goat doe. PhD Thesis, University of Stellenbosch, South Africa.

12. Greylingn JPC (2000). Reproduction traits in the Boer goat doe. Small Ruminant Research 36(2):171-177.

13. Greyling JPC, Van Niekerk CH (1991). Macroscopic uterine involution in the post-partum Boer goat. Small Ruminant Research 4(3):277-283.

14. Hafez ESE, Hafez B (2000). Folliculogenesis, Egg maturation and Ovulation. In: Reproduction in farm animal. Seventh edition, Lippincott Williams and Wilkins, A Wolters Klawer Company Philadelphia, London and New York, chapter 5.

15. Jainudeen MR, Wahid H, Hafez ESE (2000). Sheep and goats. In: ESE Hafez, B Hafez (Eds). Reproduction in farm animals, 7ed, Lippincott Williams \& Wilkins, Philadelphia, 172-181.

16. Lamond DR, Lang DR (2005). Investigation of the vaginal smear (Allen-Doisy) assay of oestrogen in ovariectomized ewes. Australian Journal of Agriculture Research 16(2): 201-210.

17. Mascarenhas R, Simoes Nunes A, Robalo Silva J (1995). Cyclic reproductive activity and efficiency of reproduction in Serrana goats. Animal Reproduction Science 38(3):223229.

18. Pretorius PS (1977). Vaginal cytological changes in the cycling and anoestrous Angora goat doe. Journal of the South African Veterinary Association 48(3):169-71.

19. Riera S (1982). Reproductive efficiency and management in goats. Proceeding $3^{\text {rd }}$ International Conference on Goat Production and Disease, Tucson, Arizona, USA, 162-174. 